\title{
Rapamycin-Polarized Th1/Tc1 Autologous T Lymphocytes
}

National Cancer Institute

\section{Source}

National Cancer Institute. Rapamycin-Polarized Th1/Tc1 Autologous T Lymphocytes.

NCI Thesaurus. Code C95080.

A population of T lymphocytes polarized by rapamycin with potential immunomodulating activity. The autolog ous $T$ cells collected from the patient were co-stimulated with antibodies to the T-cell cell surface proteins CD3 and CD28 and expanded ex vivo in the presence of rapamycin, an immunosuppressive drug, and then infused back into the same patient. Both CD3 and CD28 are required for full T-cell activation. These lymphocytes expressed anti-apoptotic bcl-2 family member proteins (reduced Bax, Bak; increased phospho-Bad); maintained mitochondrial membrane potentials; and displayed reduced apoptosis. Adoptive transfer of this type of T cell potentially induces an antiapoptotic Th1/Tc1 effector phenotype by promoting autophagy. 